\title{
The prevalence of prudence in a risky occupation
}

\author{
Robbert-Jan Schaap \\ Research Center for Environmental Economics, Alfred-Weber-Institute for Economics, \\ Heidelberg University, Bergheimer Strasse 20, 69115 Heidelberg, Germany. E-mail address: \\ robbert.schaap@awi.uni-heidelberg.de
}

\begin{abstract}
In this paper I present the first experimental measurement of prudence with a subject pool that is active in a high-risk occupation. Using a lab-in-the-field experiment I measure the prevalence of prudent preferences among 423 Chilean small-scale fishers. The prevalence of prudence in this sample is significantly lower than that found in previously measured samples. The key findings are that prudence (1) correlates with preferences for more secure occupations and (2) decreases strongly with the tenure and age of the fisher. I show that these findings are robust when controlling for risk aversion.
\end{abstract}

Keywords: Prudence, Fisheries, Natural resources, Self-insurance.

JEL: C93, D14, D81, Q22

\section{Introduction}

Prudence is associated with careful and precautionary behaviour. Formally, an individual is considered to be prudent when the third derivative of the utility function is positive (Eeckhoudt and Schlesinger, 2006). The most well-known

5 behavioural consequence of prudence is that in the presence of income risk, prudent individuals have a preference for self-insurance by accumulating precautionary savings (Leland, 1968; Sandmo, 1970; Kimball, 1990). Prudence can also imply a preference for self-protection measures (Menegatti, 2009), a distaste for down-side risk or a preference for positive skewness in distributions Ebert 10 and Wiesen, 2011). 
Economic preferences are not necessarily distributed evenly over the popjulation. Through estimations of precautionary savings, Fuchs-Schündeln and Schündeln (2005) show that prudent workers self-select into low risk occupations. The potential effect occupational selection could have on self-insurance is substantial, as it creates a situation in which those who would self-insure least when exposed to risk are in the riskiest occupations and vice versa. FuchsSchündeln and Schündeln (2005) estimate that for their sample the observed self-insurance in the form of precautionary savings is $42 \%$ lower compared to a counter-factual situation in which self-selection would not be possible. Therefore, not accounting for heterogeneous preferences can lead to biases in empirical estimations of precautionary savings and self-protection measures.

Following the development of an experimental method for measuring prudence in the lab by Eeckhoudt and Schlesinger (2006), a literature has emerged concerned with measuring the prevalence of prudence and determining its demographic correlates. The majority of experiments have found that individuals are on average prudent, indicating that prudence might be a common property of the utility function (Trautmann and van de Kuilen, 2018). However, the majority of studies use university students as their sample. Populations exposed to higher levels of risk have so far received little attention, whilst for them 30 self-insurance is particularly relevant. Some notable studies using non-student samples include Noussair et al. (2014), who test for prudence in a representative Dutch population sample and Joshi et al. (2021) who measure prudence in a sample of farmers in the West-Bengal region of India. Both these papers report that a substantial majority of their sample is prudent.

The concern that prudent preferences are less prevalent in high risk occupations is particularly relevant for natural resource users, as policy makers are focused on increasing the adaptive capabilities of vulnerable and remote communities of resource users $(\mathrm{FAO}, 2019)$. In particular, small-scale fishers face substantial risk for work place accidents (Pfeiffer and Gratz, 2016) and experience high levels of income variability due to fluctuations in resource availability and prices (Anderson et al. 2017, Kasperski and Holland, 2013). Furthermore, 
climate change is predicted to alter the productivity and dynamics of marine resources (Sumaila et al. 2011). If fishers are indeed not prudent, the predicted effectiveness of policies that promote or facilitate self-insurance might be overestimated. Such a scenario is also plausible, as Nguyen and Leung (2009) show that Vietnamese small-scale fishers are less risk averse compared to other types of workers in the same village.

In this paper I present an experimental measurement of prudence with a sample of 423 Chilean small-scale fishers. I find no evidence that fishers are prudent on average. Furthermore, I find that prudence has a strong negative correlation with age and tenure, and that prudence positively correlates with a preference for a more secure job. These findings suggest that prudent individuals are more likely to select out of fishing.

\section{Methods and data}

Between October 29th and November 24th of 2018, 26 lab-in-the field sessions were held with a total of 423 participants in the Coquimbo, Valparaíso, Bío-bío and O'Higgins regions of Chile. To measure prudence participants were presented 5 binary choices in the style proposed by Eeckhoudt and Schlesinger (2006). The choices consist of allocating a mean-zero risk to either the high or low outcome of a lottery. The lottery and mean-zero risk are two independent coin-flips, represented in Figure 11 by the European and Chilean coin respectively. The paper by Eeckhoudt and Schlesinger (2006) provides the proof that allocating the mean-zero risk to the high (low) outcome implies prudent (imprudent) preferences. The list of choices is presented in the appendix table A-1

${ }_{65}$ Participants were presented one choice at a time and did not receive feedback on the outcome of their choices until the end of the session and only one of the choices was paid out.

The first choice is parametrized to match one of the choices in Noussair et al. (2014), and will be referred to as the baseline choice. In the four subsequent 
baseline choice is increased, adding an incentive for choosing the imprudent or prudent option respectively (similar to the multiple price list format). These choices are referred to by the expected payout of the prudent option compared to the that of the imprudent option, so in the choice " +1 ", the expected payout 75 of the prudent option is one point higher than that of the imprudent option. This structure makes it possible to detect inconsistent behaviour with regard to payout maximization. For example if a participant chooses the prudent option in the baseline choice and subsequently chooses the imprudent option, in the $"+1 "$ choice, then the participants made an inconsistent choice.

Following the literature, prudence is measured as the number of prudent choices that the participant has made out of the 5 possible (Ebert and Wiesen 2011; Noussair et al., 2014). Individuals make errors and can be indifferent between options. This creates noise in the individual choices. However if the underlying preference for prudence is stronger, the participant is less likely to commit an error and more likely to choose the prudent option. The number of prudent choices then creates a ranking of subjects with regard to the strength of their underlying prudent preferences.

Additionally, risk aversion was measured using the Gneezy-Potters risky investment method (Charness et al., 2013). Participants are asked to distribute 906 points between a safe option, with a certain payout of 1 point per invested point, and a risky option. The points in the risky option were either lost or tippled, each with $50 \%$ probability. The outcome variable is the number of points invested into the risky option, thus greater values indicate weaker risk aversion and stronger risk tolerance. With this method, participants that invest

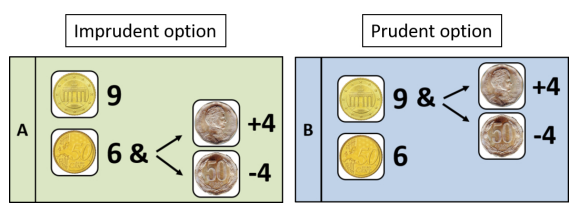

Figure 1: The figure shows the two options in the baseline choice task. 
less than the full endowment can be considered risk averse as the expected value of the risky option is strictly greater than that of the safe option. Those that do invest the full endowment are either risk neutral or risk seeking.

The participants were also asked a general risk question in the form: "Generally speaking, are you a person who is willing to take risks?". Participants could answer on a 6-point Likert-scale, with 0-completely unwilling and 5-completely willing.

An unrelated one-shot public goods game was conducted during the sessions. After completing the experiments participants filled a questionnaire regarding their demographics and fishing activities. At the end of the session one of the choices from the risk, prudence or public good experiment was randomly chosen to be paid out. The preference questions and demographic survey were answered on tablets running OpenDataKit survey software (Hartung et al. 2010). The sessions lasted between 1.5 and 2 hours and had between 8 and 22 participants. Participants were paid 10,000 Chilean pesos (CLP) for finishing the survey and could earn an additional 0 to 24,000 CLP with the incentivized preference questions. The average payout was 18,100 CLP, which is equivalent to 23,76 Euro.

\section{Results}

\subsection{Prevalence of prudence}

First I test whether the sample as a whole exhibits prudent preferences. For the baseline choice I find that $53.7 \%$ of participants chose the prudent option. This does not differ significantly from a random choice or $50 \%$ (two-sided binomial test, $p=0.1446, n=423)$. As expected participants are more likely to choose the prudent option when the expected value increases. The difference 120 is 5.9 percentage points (pp) between the baseline and the +2 choice (Twoproportions z-test, $p=0.082$ ), and 8.9 pp between the -2 and +2 choice (Twoproportions z-test, $p<0.01)$. Figure 2 shows the proportion of participants that chose the prudent option in each choice. 
Next, I compare the fraction of prudent choices in the baseline choice task

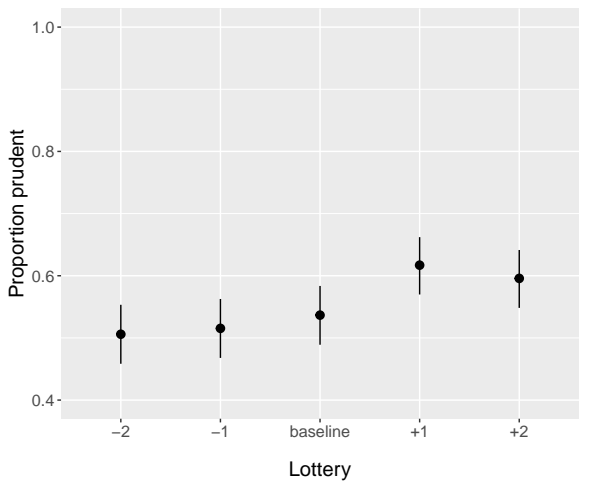

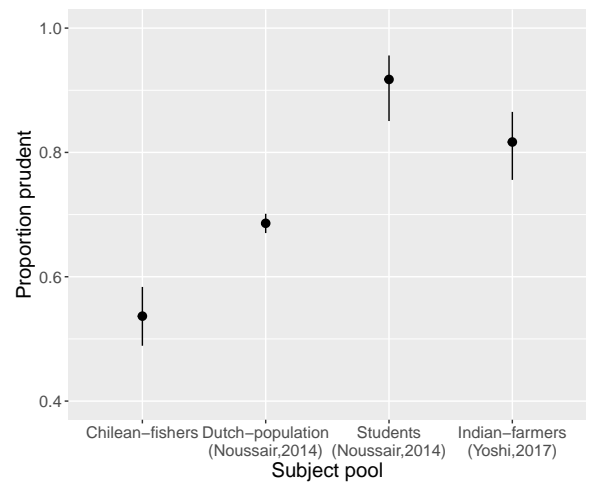

Figure 2: The left graph reports the fraction of the sample that chose the prudent option in each of the five choice tasks. The number on the $\mathrm{x}$-axis reports the expected value of the prudent option compared to the imprudent option. The right graph compares the fraction of prudent choices in the baseline choice task to those in other studies. The bars indicate the $95 \%$ binomial confidence intervals. 
coefficient: $-0.10, \mathrm{p}=0.04 \%$ ), which indicates a positive correlation between prudence and risk aversion. The correlation coefficient between the experimental risk task and the baseline choice is similar but only marginally significant (Spearman rank correlation coefficient: $-0.09, \mathrm{p}=0.06 \%$ ). This corresponds with previous findings, as several papers find that prudence and risk aversion are moderately correlated, with Spearman correlation coefficient ranging between 0.251 and 0.312 (Noussair et al. 2014, Brunette and Jacob, 2019).

\subsection{Demographic correlates}

Table 1 presents the ordered probit regression coefficients for the demographic correlates of prudence and risk aversion. The dependent variable in specifications 1 and 2 is the number of prudent choices, in specification 3 it is the points invested into the risky option and in specification 4 it is the participants answer to the general risk question. In order to reduce noise, specification 2 excludes participants that failed the comprehension question or chose inconsistently with regard to income maximization. Tenure (years active as a fisher) is included separately from age in the appendix table A-2 due to concerns about collinearity; the Pearson correlation coefficient for tenure and age is 0.75 .

Both age and tenure have a strong and significant negative correlation with prudence $(p<0.01)$. The literature reports both positive (Colasante and Riccetti, 2020) and no significant age effects (Trautmann and van de Kuilen, 2018), indicating that declining prudence with age is not a general process. Similarly, age correlates positively with the experimental measure for risk tolerance and tenure correlates positively with both measures of risk tolerance. This is in contrast to the general findings in the literature, which suggest that individuals become more risk averse as they age (Falk et al. 2018, Schildberg-Hörisch, 2018). It is unclear if these correlations are strictly due to ageing or if a confounding process such as out-selection drives these effects.

口 Male participants make more prudent choices on average $(p<0.01)$. Ebert and Wiesen (2014) report a marginally significant gender effect in the opposite direction, indicating that women might be more prudent. Participants with chil- 
dren and boat owners are less prudent on average $(p<0.05)$, these coefficients are only significant in specification 1 . In contrast to the previous literature, I find no significant effect for education on prudence (Trautmann and van de Kuilen, 2018). This could be due to selection, as those that have attained high levels of educations selected into a high risk occupation which generally does not require a specific degree. Prudence has a positive correlation with the use of formal networks (banks and government) in times of need $(p<0.01)$, which relates to the finding of Noussair et al. (2014), who report that prudence correlates with the usage of savings accounts and that prudent individuals are less likely to have credit card debt.

\subsection{Preference for secure job}

Lastly, I test whether prudence correlates with a stated preference for a secure job using a logistic regression. In specification 1 of Table 2 I show that fishers that make more prudent choices are more likely to prefer a secure job over fishing $(p<0.01)$. Boat owners, who are more invested in the fishery, are also less likely to prefer a secure job $(p<0.01)$. Specification 2 shows that the findings are robust for the subsample of consistent participants. Specifications 3 and 4 include the experimental and survey measure for risk aversion respectively. I find no correlation between the experimental measure and a preference for a secure job. The survey measure has a negative correlation with a preference for secure a job $(p<0.05)$, meaning that participants with lower self-reported risk tolerance are more likely to prefer a secure job over fishing. The coefficient for prudence remains significant when controlling for either measure of risk aversion.

\section{Conclusion and discussion}

Using a lab-in-the-field experiment with a sample of 423 Chilean small-scale fishers, I do not find that fishers are prudent on average. The low prevalence of prudence is remarkable as a recent review by Trautmann and van de Kuilen (2018) reports that 16 out of 17 previous studies found their sample to have 
prudent preferences on average. The low prevalence of prudence among fishers

is likely due to the substantial risks inherent to their occupation and prudent individuals selecting into safer occupations (Fuchs-Schündeln and Schündeln 2005). Two results suggest that the low prevalence of prudence is indeed due to prudent individuals being more likely to exit fisheries. First, prudence strongly decreases with the tenure and age of the participants. The intuition being that more prudent fishers select out of fishing earlier. Second, prudent participants are more likely to state that they would prefer a secure job over fishing.

\begin{tabular}{|c|c|c|c|c|}
\hline & \multicolumn{4}{|c|}{ Dependent variable: } \\
\hline & \multicolumn{2}{|c|}{ Prudent choices } & \multicolumn{2}{|c|}{ Risk tolerance } \\
\hline & (1) & $(2)$ & $\begin{array}{c}\text { Experiment } \\
(3) \\
\end{array}$ & $\begin{array}{c}\text { Survey } \\
(4)\end{array}$ \\
\hline Age & $\begin{array}{c}-0.030^{* * *} \\
(0.004)\end{array}$ & $\begin{array}{c}-0.033^{* * *} \\
(0.009)\end{array}$ & $\begin{array}{c}0.014^{* * *} \\
(0.004)\end{array}$ & $\begin{array}{c}0.003 \\
(0.002)\end{array}$ \\
\hline Gender & $\begin{array}{c}-0.186^{* * *} \\
(0.052)\end{array}$ & $\begin{array}{c}-0.331^{* *} \\
(0.129)\end{array}$ & $\begin{array}{l}-0.150 \\
(0.112)\end{array}$ & $\begin{array}{l}-0.042 \\
(0.063)\end{array}$ \\
\hline High School & $\begin{array}{c}0.075 \\
(0.110)\end{array}$ & $\begin{array}{c}0.073 \\
(0.187)\end{array}$ & $\begin{array}{c}0.051 \\
(0.080)\end{array}$ & $\begin{array}{c}0.058 \\
(0.116)\end{array}$ \\
\hline Spouse & $\begin{array}{c}0.162 \\
(0.149)\end{array}$ & $\begin{array}{l}0.432^{*} \\
(0.222)\end{array}$ & $\begin{array}{c}0.231 \\
(0.144)\end{array}$ & $\begin{array}{c}0.076 \\
(0.109)\end{array}$ \\
\hline Children & $\begin{array}{c}-0.278^{* *} \\
(0.135)\end{array}$ & $\begin{array}{l}-0.427 \\
(0.268)\end{array}$ & $\begin{array}{l}-0.032 \\
(0.079)\end{array}$ & $\begin{array}{c}0.059 \\
(0.162)\end{array}$ \\
\hline Formal Networks & $\begin{array}{c}0.329^{* * *} \\
(0.075)\end{array}$ & $\begin{array}{c}0.453^{* * *} \\
(0.138)\end{array}$ & $\begin{array}{l}-0.130 \\
(0.094)\end{array}$ & $\begin{array}{c}0.125 \\
(0.113)\end{array}$ \\
\hline Boat Owner & $\begin{array}{c}-0.194^{* *} \\
(0.088) \\
\end{array}$ & $\begin{array}{l}-0.200 \\
(0.180) \\
\end{array}$ & $\begin{array}{c}0.075 \\
(0.119) \\
\end{array}$ & $\begin{array}{c}-0.208^{*} \\
(0.117) \\
\end{array}$ \\
\hline Observations & 406 & 184 & 406 & 388 \\
\hline
\end{tabular}

Table 1: Table reports ordered probit regression coefficients of the demographic correlates of prudence and risk tolerance. Specifications (2) excludes participants that did not pass comprehension criteria. Robust standard errors are clustered on the level of the landing site. 


\begin{tabular}{|c|c|c|c|c|}
\hline & \multicolumn{4}{|c|}{ Dependent variable: } \\
\hline & \multicolumn{4}{|c|}{ Preference Salary } \\
\hline & $(1)$ & $(2)$ & $(3)$ & $(4)$ \\
\hline Prudent Choices & $\begin{array}{c}0.081^{* * *} \\
(0.030)\end{array}$ & $\begin{array}{c}0.134^{* * *} \\
(0.038)\end{array}$ & $\begin{array}{c}0.082^{* * *} \\
(0.030)\end{array}$ & $\begin{array}{l}0.077^{* *} \\
(0.030)\end{array}$ \\
\hline Risk tolerance (Experiment) & & & $\begin{array}{c}0.055 \\
(0.054)\end{array}$ & \\
\hline Risk tolerance (Survey) & & & & $\begin{array}{c}-0.070^{* *} \\
(0.031)\end{array}$ \\
\hline Age & $\begin{array}{c}0.004 \\
(0.006)\end{array}$ & $\begin{array}{c}0.003 \\
(0.009)\end{array}$ & $\begin{array}{c}0.003 \\
(0.006)\end{array}$ & $\begin{array}{c}0.004 \\
(0.006)\end{array}$ \\
\hline Female & $\begin{array}{c}0.328^{* *} \\
(0.140)\end{array}$ & $\begin{array}{l}-0.043 \\
(0.214)\end{array}$ & $\begin{array}{c}0.344^{* *} \\
(0.141)\end{array}$ & $\begin{array}{l}0.260^{*} \\
(0.139)\end{array}$ \\
\hline High School & $\begin{array}{l}-0.160 \\
(0.158)\end{array}$ & $\begin{array}{l}-0.365 \\
(0.234)\end{array}$ & $\begin{array}{l}-0.167 \\
(0.159)\end{array}$ & $\begin{array}{l}-0.129 \\
(0.160)\end{array}$ \\
\hline Spouse & $\begin{array}{l}-0.067 \\
(0.173)\end{array}$ & $\begin{array}{l}-0.321 \\
(0.251)\end{array}$ & $\begin{array}{l}-0.082 \\
(0.173)\end{array}$ & $\begin{array}{l}-0.035 \\
(0.198)\end{array}$ \\
\hline Children & $\begin{array}{l}-0.041 \\
(0.204)\end{array}$ & $\begin{array}{c}0.336 \\
(0.388)\end{array}$ & $\begin{array}{l}-0.041 \\
(0.202)\end{array}$ & $\begin{array}{l}-0.034 \\
(0.209)\end{array}$ \\
\hline Formal Network & $\begin{array}{c}0.139 \\
(0.111)\end{array}$ & $\begin{array}{c}0.312 \\
(0.234)\end{array}$ & $\begin{array}{c}0.149 \\
(0.118)\end{array}$ & $\begin{array}{c}0.139 \\
(0.108)\end{array}$ \\
\hline Boat owner & $\begin{array}{c}-0.638^{* * *} \\
(0.173)\end{array}$ & $\begin{array}{c}-0.834^{* *} \\
(0.395)\end{array}$ & $\begin{array}{c}-0.642^{* * *} \\
(0.167)\end{array}$ & $\begin{array}{c}-0.668^{* * *} \\
(0.163)\end{array}$ \\
\hline Constant & $\begin{array}{l}-0.361 \\
(0.379) \\
\end{array}$ & $\begin{array}{l}-0.407 \\
(0.637) \\
\end{array}$ & $\begin{array}{l}-0.519 \\
(0.346) \\
\end{array}$ & $\begin{array}{l}-0.146 \\
(0.453) \\
\end{array}$ \\
\hline Observations & 390 & 177 & $\begin{array}{c}390 \\
250096\end{array}$ & $\begin{array}{l}375 \\
-241925\end{array}$ \\
\hline Log Likelihood & -251.577 & -110.487 & -250.996 & -241.925 \\
\hline Note: & & $* p<0.10$ & $* * 0.05$ & ${ }^{* *} p<0.01$ \\
\hline
\end{tabular}




\section{Acknowledgements}

I am grateful to Sarah Henriquez, Jose Merino, Exequiel Gonzalez Poblete and Karin Silva for invaluable research assistance. Further I would like to thank

\section{References}

Anderson, S.C., Ward, E.J., Shelton, A.O., Adkison, M.D., Beaudreau, A.H., Brenner, R.E., Haynie, A.C., Shriver, J.C., Watson, J.T., Williams, B.C., 2017. Benefits and risks of diversification for individual fishers. Proceed$220 \quad \square$

$$
\text { //www.pnas.org/content/114/40/10797, doi 10.1073/pnas.1702506114, }
$$
arXiv:http://www.pnas.org/content/114/40/10797.full.pdf.

Brunette, M., Jacob, J., 2019. Risk aversion, prudence and temperance: An experiment in gain and loss. Research in Economics 73, 225 174-189. URL: http://www.sciencedirect.com/science/article/pii/ S1090944319300778, doi https://doi.org/10.1016/j.rie.2019.04.004.

Charness, G., Gneezy, U., Imas, A., 2013. Experimental methods: Eliciting risk preferences. Journal of Economic Behavior \& Organization 87,

a 43 - 51. URL: http://www.sciencedirect.com/science/article/pii/ S016726811200282X, doi/https://doi.org/10.1016/j.jebo.2012.12.023

Colasante, A., Riccetti, L., 2020. Risk aversion, prudence and temperance: It is a matter of gap between moments. Journal of

口 Behavioral and Experimental Finance 25, 100262. URL: https: 
//www.sciencedirect.com/science/article/pii/S2214635019301522,

Ebert, S., Wiesen, D., 2011. Testing for prudence and skewness seeking.

¿ Management Science 57, 1334-1349. URL: http://www.jstor.org/stable/ 25835779

Ebert, S., Wiesen, D., 2014. Joint measurement of risk aversion, prudence, and 240 temperance. Journal of Risk and Uncertainty 48, 231-252. URL: https:// EconPapers.repec.org/RePEc:kap:jrisku:v:48:y:2014:i:3:p:231-252.

Eeckhoudt, L., Schlesinger, H., 2006. Putting risk in its proper place. American

\ Economic Review 96, 280-289. URL: http://www.aeaweb.org/articles? $i d=10.1257 / 000282806776157777$, doi $10.1257 / 000282806776157777$.

${ }_{245}$ Falk, A., Becker, A., Dohmen, T., Enke, B., Huffman, D., Sunde, U., 2018. Global Evidence on Economic Preferences*. The Quarterly Journal of Economics 133, 1645-1692. URL: https://doi.org/10.1093/qje/qjy013, doi:10.1093/qje/qjy013.

FAO, 2019. Social protection in small-scale fisheries and aquaculture in Latin America and the Caribbean. FAO. Santiago de Chile 48 pp. Licence: CC BY-NC-SA 3.0 IGO.

Fuchs-Schündeln, N., Schündeln, M., 2005. Precautionary savings and selfselection: Evidence from the german reunification "experiment". The Quarterly Journal of Economics 120, 1085-1120. URL: http://www.jstor.org/ stable/25098763.

Hartung, C., Lerer, A., Anokwa, Y., Tseng, C., Brunette, W., Borriello, G., 2010. Open data kit: Tools to build information services for developing regions, in: Proceedings of the 4th ACM/IEEE International Conference on Information and Communication Technologies and Development, ACM,

260 \New York, NY, USA. pp. 18:1-18:12. URL: http://doi.acm.org/10.1145/ 2369220.2369236, doi:10.1145/2369220.2369236. 
Joshi, K., Ranganathan, T., Ranjan, R., 2021. Exploring higher order risk preferences of farmers in a water-scarce region: Evidence from a field experiment in west bengal, india. Journal of Quantitative Economics URL: https://doi. org/10.1007/s40953-021-00232-4, doi:10.1007/s40953-021-00232-4

Kasperski, S., Holland, D.S., 2013. Income diversification and risk for fishermen. q Proceedings of the National Academy of Sciences 110, 2076-2081. URL: http: //www.pnas.org/content/110/6/2076 doi 10.1073/pnas.1212278110, arXiv:http://www.pnas.org/content/110/6/2076.full.pdf,

Kimball, M.S., 1990. Precautionary saving in the small and in the large. Econometrica 58, 53-73. URL: http://www.jstor.org/stable/2938334.

Leland, H.E., 1968. Saving and uncertainty: The precautionary demand for saving. The Quarterly Journal of Economics 82, 465-473.

(1) URL: https://EconPapers.repec.org/RePEc:oup:qjecon:v:82:y:1968: $i: 3: p: 465-473$.

Menegatti, M., 2009. Optimal prevention and prudence in a two-period q model. Mathematical Social Sciences 58, 393 - 397. URL: http: //wWw.sciencedirect.com/science/article/pii/S0165489609000626, doi:https://doi.org/10.1016/j.mathsocsci.2009.07.001.

Nguyen, Q., Leung, P., 2009. Do Fishermen Have Different Attitudes Toward Risk? An Application of Prospect Theory to the Study of Vietnamese Fishermen. Journal of Agricultural and Resource Economics 34, 1-21. URL: a https://ideas.repec.org/a/ags/jlaare/57624.html, doi:10.22004/ag. econ.57624

Noussair, C.N., Trautmann, S.T., van de Kuilen, G., 2014. Higher order risk attitudes, demographics, and financial decisions. The Review of Economic Studies 81, 325-355. URL: http://dx.doi.org/10.1093/restud/rdt032, doi:10.1093/restud/rdt032. 
Pfeiffer, L., Gratz, T., 2016. The effect of rights-based fisheries management on risk taking and fishing safety. Proceedings of n the National Academy of Sciences 113, 2615-2620. URL: https: //www.pnas.org/content/113/10/2615 doi 10.1073/pnas.1509456113 arXiv:https://www.pnas.org/content/113/10/2615.full.pdf

Sandmo, A., 1970. The effect of uncertainty on saving decisions. The Review 295 of Economic Studies 37, 353-360. URL: http://www.jstor.org/stable/ 2296725

Schildberg-Hörisch, H., 2018. Are risk preferences stable? Journal of Economic 19 Perspectives 32, 135-54. URL: https://www . aeaweb.org/articles?id=10. $1257 /$ jep.32.2.135, doi $10.1257 /$ jep.32.2.135

300 Sumaila, U.R., Cheung, W.W.L., Lam, V.W.Y., Pauly, D., Herrick, S., 2011. Climate change impacts on the biophysics and economics of world fishq eries. Nature Climate Change 1, 449-456. URL: https://doi.org/10.1038/ nclimate1301, doi:10.1038/nclimate1301.

Trautmann, S.T., van de Kuilen, G., 2018. Higher order risk attitudes: 305 A review of experimental evidence. European Economic Review 103, 1 108 - 124. URL: http://www.sciencedirect.com/science/article/pii/

1. S0014292118300102, doi:https://doi.org/10.1016/j.euroecorev.2018. 01.007 . 


\section{Appendix}

\begin{tabular}{lcrcc}
\hline & Option A & Option B & Frequency A & Frequency B \\
\hline Baseline & $9 \mid 6+(4 \mid-4)$ & $9+(4 \mid-4) \mid 6$ & 196 & 227 \\
Prudence +1 & $9 \mid 6+(4 \mid-4)$ & $10+(4 \mid-4) \mid 7$ & 162 & 261 \\
Prudence - 1 & $10 \mid 7+(4 \mid-4)$ & $9+(4 \mid-4) \mid 6$ & 205 & 218 \\
Prudence +2 & $9 \mid 6+(4 \mid-4)$ & $11+(4 \mid-4) \mid 8$ & 171 & 252 \\
Prudence - 2 & $11 \mid 8+(4 \mid-4)$ & $9+(4 \mid-4) \mid 6$ & 209 & 214 \\
\hline
\end{tabular}

Table A-1: List of lotteries and frequency of participant choices. The notation for the lotteries is as follows, $[H \mid L]$ would indicate a lottery that has outcomes $H$ and $L$ with equal probabilities. The lotteries for prudence have the following structure $[H+(l \mid h) \mid L]$, which indicates that the lottery $H+(l \mid h)$ and the outcome $L$ occur with the same probability. 


\begin{tabular}{|c|c|c|c|c|}
\hline & \multicolumn{4}{|c|}{ Dependent variable: } \\
\hline & \multicolumn{2}{|c|}{ Prudent choices } & \multicolumn{2}{|c|}{ Risk tolerance } \\
\hline & (1) & $(2)$ & $\begin{array}{c}\text { Experiment } \\
\text { (3) }\end{array}$ & $\begin{array}{c}\text { Survey } \\
(4)\end{array}$ \\
\hline Tenure & $\begin{array}{c}-0.022^{* * *} \\
(0.004)\end{array}$ & $\begin{array}{c}-0.027^{* * *} \\
(0.010)\end{array}$ & $\begin{array}{c}0.012^{* * *} \\
(0.004)\end{array}$ & $\begin{array}{l}0.008^{* *} \\
(0.004)\end{array}$ \\
\hline Female & $\begin{array}{c}-0.148^{* * *} \\
(0.055)\end{array}$ & $\begin{array}{c}-0.241^{* *} \\
(0.116)\end{array}$ & $\begin{array}{l}-0.163 \\
(0.109)\end{array}$ & $\begin{array}{l}-0.019 \\
(0.078)\end{array}$ \\
\hline High School & $\begin{array}{c}0.127 \\
(0.122)\end{array}$ & $\begin{array}{c}0.086 \\
(0.245)\end{array}$ & $\begin{array}{c}0.033 \\
(0.097)\end{array}$ & $\begin{array}{c}0.102 \\
(0.109)\end{array}$ \\
\hline Spouse & $\begin{array}{c}0.153 \\
(0.153)\end{array}$ & $\begin{array}{c}0.483^{* * *} \\
(0.185)\end{array}$ & $\begin{array}{c}0.229 \\
(0.144)\end{array}$ & $\begin{array}{c}0.059 \\
(0.108)\end{array}$ \\
\hline Children & $\begin{array}{l}-0.279 \\
(0.171)\end{array}$ & $\begin{array}{l}-0.475 \\
(0.297)\end{array}$ & $\begin{array}{l}-0.023 \\
(0.089)\end{array}$ & $\begin{array}{c}0.057 \\
(0.161)\end{array}$ \\
\hline Formal Networks & $\begin{array}{c}0.281^{* * *} \\
(0.072)\end{array}$ & $\begin{array}{l}0.405^{* *} \\
(0.168)\end{array}$ & $\begin{array}{l}-0.110 \\
(0.095)\end{array}$ & $\begin{array}{c}0.123 \\
(0.117)\end{array}$ \\
\hline Boat Owner & $\begin{array}{l}-0.098 \\
(0.094) \\
\end{array}$ & $\begin{array}{l}-0.089 \\
(0.184) \\
\end{array}$ & $\begin{array}{c}0.026 \\
(0.115) \\
\end{array}$ & $\begin{array}{c}-0.250^{* *} \\
(0.127) \\
\end{array}$ \\
\hline Observations & 406 & 184 & 406 & 388 \\
\hline
\end{tabular}

Table A-2: Table reports ordered probit regression coefficients of the demographic correlates of prudence and risk tolerance. Specifications (2) excludes participants that did not pass comprehension criteria. Robust standard errors are clustered on the level of the landing site. Table replicates Table 1 with tenure as explanatory variable instead of age. 